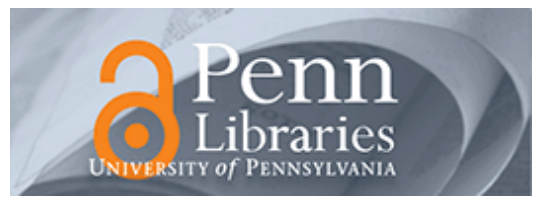

University of Pennsylvania

ScholarlyCommons

Management Papers

Wharton Faculty Research

$11-2013$

\title{
The Business Model: A Theoretically Anchored Robust Construct for Strategic Analysis
}

Christoph Zott

Raphael H. Amit

University of Pennsylvania

Follow this and additional works at: https://repository.upenn.edu/mgmt_papers

Part of the Business Administration, Management, and Operations Commons

\section{Recommended Citation}

Zott, C., \& Amit, R. H. (2013). The Business Model: A Theoretically Anchored Robust Construct for Strategic Analysis. Strategic Organization, 11 (4), 403-411. http://dx.doi.org/10.1177/1476127013510466

This paper is posted at ScholarlyCommons. https://repository.upenn.edu/mgmt_papers/70

For more information, please contact repository@pobox.upenn.edu. 


\title{
The Business Model: A Theoretically Anchored Robust Construct for Strategic Analysis
}

\begin{abstract}
Anchored in our research on business models, we delineate in this article a future research agenda. We establish that the theoretical and empirical advancements in business model research provide solid conceptual and empirical foundations on which scholars can build in order to explore a range of important, yet unanswered research questions. We draw inspiration on the direction of the business model research agenda by briefly reviewing several distinct bodies of literature adjacent to the business model literature including new organizational forms, ecosystems, activity systems, and value chain. In doing so, we also distinguish the business model concept from seemingly similar concepts that have been proposed by researchers.
\end{abstract}

\section{Keywords}

entrepreneurship, strategy formulation, strategy content, resource-based view, firm performance

\section{Disciplines}

Business Administration, Management, and Operations 


\title{
THE BUSINESS MODEL: A THEORETICALLY ANCHORED ROBUST CONSTRUCT FOR STRATEGIC ANALYSIS ${ }^{1}$
}

\author{
Christoph Zott \\ IESE Business School \\ Av. Pearson 21 \\ 08034 Barcelona (Spain) \\ Phone: +34 936024096 \\ Fax: +34932534343 \\ Email: czott@iese.edu \\ and \\ Raphael Amit \\ The Wharton School \\ University of Pennsylvania \\ 3620 Locust Walk \\ Philadelphia, PA 19104-6370 (USA) \\ Phone: (215) 898-7731 \\ Fax: (215) 573-7189 \\ Email: amit@wharton.upenn.edu
}

October 7, 2013

\section{Accepted for Publication in Strategic Organization}

\footnotetext{
${ }^{1}$ The authors gratefully acknowledge the very helpful comments and suggestions of the Editors. Christoph Zott acknowledges the support of IESE in sponsoring this research, and of the Ministry of Science and Innovation of Spain (grant ECO2012-38131). Raffi Amit is grateful to the Robert B. Goergen Chair for financial support of his research.
} 


\title{
THE BUSINESS MODEL: A THEORETICALLY ANCHORED ROBUST CONSTRUCT FOR STRATEGIC ANALYSIS
}

\begin{abstract}
Anchored in our research on business models we delineate in this article a future research agenda. We establish that the theoretical and empirical advancements in business model research provide solid conceptual and empirical foundations on which scholars can build in order to explore a range of important, yet unanswered research questions. We draw inspiration on the direction of the business model research agenda by briefly reviewing several distinct bodies of literature adjacent to the business model literature including: new organizational forms, ecosystems, activity systems, and value chain. In doing so, we also distinguish the business model concept from seemingly similar concepts that have been proposed by researchers.
\end{abstract}




\section{THE BUSINESS MODEL: A THEORETICALLY ANCHORED ROBUST CONSTRUCT FOR STRATEGIC ANALYSIS}

\section{Business Model Research: State of the Art (Present)}

In our research on business models during the past decade and half, we have attempted to establish the business model as a construct that is useful for researchers and practitioners alike to come to grips with the new realities of doing business in a highly interconnected world. As part of our research agenda, we have developed the theoretical roots of the business model (Amit \& Zott, 2001). We have argued that business models can create value through efficiency (anchored in transaction costs economics), novelty (through Schumpeterian innovation), complementarities (anchored in resource-based theory), and lock-in (inherent in strategic networks). The emphasis of the business model perspective on value creation calls for integrating these theories to potentially heighten our understanding of the complex processes and mechanics that drive wealth creation.

The business model describes the system of interdependent activities that are performed by the firm and by its partners, and the mechanisms that link these activities to each other (Zott \& Amit, 2010). A business model is thus a template that depicts the way the firm conducts its business. It is crafted by a focal firm's managers in order to best meet the perceived needs of its customers. To fully address the market opportunity, the focal firm's business model often spans across the firm and its industry boundaries. While it is anchored on the focal firm, it is market centric and designed so as to enable the focal firm not only to enhance total value for all business model participants but also to appropriate 
a share of the value created. This conceptualization is broadly consistent with the emerging literature on business models (e.g., Casadesus-Masanell \& Ricart, 2010; Chesbrough \& Rosenbloom, 2002; Teece, 2007). Researchers have begun to converge on the following common themes that characterize business models (Zott, Amit, \& Massa, 2011): (a) business models center on the logic of how value is created for all stakeholders, not just how it is captured by the focal firm; (b) activities performed by the focal firm as well as by partners, suppliers, and even customers play an important role; (c) business models emphasize a system-level, holistic approach towards explaining how firms "do business"; and (d) the business model is emerging as a new level and unit of analysis.

In Zott and Amit $(2007,2008)$ we show empirically that the design of the business model is indeed central to value creation. In particular, in Zott and Amit (2007), we have analyzed the performance implications for entrepreneurial firms of business model designs by considering two distinct effects: the total value creation potential of the business model and the focal firm's ability to appropriate that value. We find through large sample, cross-sectional empirical analyses of young firms that introducing novel business models positively influences performance, even when the environment switches from resource-rich to resource-poor. Further, in Zott and Amit (2008) we examine theoretically and empirically the fit between a firm's product market strategy and its business model. We find that the business model and product market strategy are complements, not substitutes. As well, we establish that novelty-centered business models - coupled with product market strategies that emphasize differentiation, cost leadership, or early market entry — can enhance firm performance. In Amit and Zott 
(2012) we highlight the important role of business model innovation in value appropriation and in Amit and Zott (2013) we draw on the broad design literature to derive four antecedents of business model design, including Goals, Templates, Stakeholder Activities, and Environmental Constraints.

As Romme (2003) notes, the purpose of design is to produce systems that do not yet exist—a key task for entrepreneurial leaders. Indeed, in (re-)designing their business models, entrepreneurs and senior executives throughout the world, in new as well as existing companies, have been leveraging recent technological developments. Among other things, this has contributed to a shift in the locus of competitive advantage from the firm and its internal stakeholders (e.g., management, shareholders, and employees) to its activity system, which encompasses external stakeholders such as partners, vendors, and customers. Thus, both new and established firms have become increasingly interested in designing and innovating their business models.

\section{Reflections on "The Business Model: Present and Future—Beyond a Skeuomorph"}

In "The Business Model: Present and Future-Beyond a Skeuomorph," the authors argue that "the use of the term business model as a description of how a traditional venture operates is strong on redundancy and weak on theoretical grounding." While recognizing the practical value of business model concepts in providing a common language among stakeholders and a cognitive tool for visualization, Arend (this issue) points out five 
concerns he has about the current state and use of business model concepts. We address each concern in the following discussion.

1. Unresolved overlap of the business model idea with established concepts, levels of analysis, theories, etc.

We agree that overlap with established concepts can be a problem with some studies on business models, but not with all. Arend implicitly assumes here that there is one established, commonly agreed upon "business model idea." We do not think, however, that this is the case (see Zott et al., 2011) and hence reject the general claim. Nevertheless, we believe that this point is a valid reminder to business model researchers that they need to define their concepts properly and to distinguish them carefully_conceptually as well as empirically_-from the received concepts in the literature. It also needs to be shown empirically that the construct has convergent as well as discriminant validity (as we have done in Zott \& Amit 2007, 2008) to establish its empirical validity. Defining the business model broadly, for example, as a "description of how a traditional venture operates," as Arend does, lacks specificity and opens the door to ambiguities, misunderstandings, and overlap.

\section{Lack of independence of the concept from other levels of analysis}

As a level of analysis, i.e., "the unit to which the data are assigned for hypothesis testing and statistical analysis" (Rousseau, 1985:4), the business model is nested between the firm and the network. It is centered on a focal firm, yet spans focal firm boundaries by including stakeholders with which the firm interacts when it produces and delivers value. As such, the business model is linked to other levels of analysis, 
although it is distinct. The fact that the business model links to other levels of analysis and relates to notions of entrepreneurship and design is not a problem per se. It rather points to the need to conduct multi-level research and to integrate theoretical perspectives, as we have long advocated (Amit \& Zott, 2001).

\section{Lack of uniqueness as a level of analysis}

The fact that every firm has a business model does not imply that the concept lacks distinctiveness as a level of analysis or that it lacks strategic importance. Whether the business model can be considered a new level of analysis depends on the definition of the term that is put forward by researchers. We agree that some definitions that are all-encompassing (according to which the business model comprises almost everything related to the firm: resources, activities, products, value propositions, incentives, organizational policies, revenue streams, cost structures, etc.) make it very difficult to see what the business model is not and how it differs from the firm or the organization (or other levels of analysis) at large. Thus, while Arend's general claim of "little value added" needs to be again contested, it is incumbent upon business model researchers to carefully define the business model and delineate it as a distinct level of analysis.

\section{Lack of any consistent definition of the term "business model"}

As explained above, we wholeheartedly agree with the need to provide clean and clear definitions, otherwise conversations about business models risk becoming highly ambiguous, vague, and confusing. However, the authors' own attempt to 
distinguish the notions of business model and business model (while still referring in their essay to the business model without any italicized word) seems ad hoc and confusing. It requires further theoretical and empirical justification to be a useful distinction for researchers and practitioners.

Furthermore, as we have observed elsewhere (Zott et al., 2011), based on our indepth analysis of the literature, we identify signs of convergence towards consistent themes within the business model definitions provided, so the state of the field is not as hopeless and dreary as Arend seems to suggest. We understand the desire of researchers to have one commonly agreed upon definition so that a field can move forward and make progress more quickly and easily. However, our own analysis leads us to believe that progress can be made even in the absence of a single, unified definition. What is necessary, though, is a clear statement about the research objectives in every future study on business models, and a clear definition and explanation of the business model concept adopted in order to answer the research question.

\section{Lack of solid empirical support}

While in Zott and Amit (2007, 2008) we have provided robust empirical support for the distinctiveness of the business model construct, we agree with Arend that additional empirical support would contribute to the acceptance of the concept. We note, however, that ordinarily empirical works follow conceptual development. Therefore additional theory development is also warranted. It might be worthwhile 
considering, as an example, that the resource-based view of the firm was developed as a broadly accepted theoretical framework for understanding heterogeneity among firms, before significant empirical work could emerge.

\section{Business Model: Research Opportunities for the Future}

The title of Arend's article mentions a skeuomorph, which is "a design feature that is carried forth from the original version of a product in order to make people feel comfortable with the new device" (Wikipedia). An example would be the click sound on a digital camera, which is played from an audio file and meant to mimic the original sound of a camera shutter opening and closing. Whereas Arend probably refers to the concept to suggest that the term business model is often simply used as a label to capture an audience's attention, we believe that there is much more substance to the concept and how it has been studied in the past. We share with the author the conviction that there are ample and rich opportunities for future research on the topic. Below, we map out a research agenda for the study of business models by briefly discussing several distinct bodies of literature adjacent to the business model literature: new organizational forms, ecosystems, activity systems, and value chain. In doing so, we aim at delineating the business model concept (as we define it) from seemingly similar concepts that have been proposed by researchers. At the same time, we draw inspiration from these literatures for future research on business models.

New organizational forms. The 1980s and 1990s produced extensive literature under the label of "new organizational forms" (Daft \& Levin, 1993). Terms such as post-industrial 
organization, post-bureaucratic organization, modular organization, cluster organization, virtual corporation, network organization, and perpetual matrix were introduced and intended to represent the so-called new organizational forms (e.g., Djelic \& Ainamo, 1999; Zajac, Golden, \& Shortell, 1991). The holistic approach of this literature as well as the quest for a more meaningful unit of analysis beyond the focal firm were important preludes to the business model perspective.

According to Romanelli (1991), the concept of new organizational form refers to those characteristics that identify the organization as a distinct entity and classify it as a member of a particular group of similar organizations. Others have emphasized a more institutional and cognitive perspective. McKendrick and Carroll (2001), for example, defined organizational forms as external codes of identity. The concept thus differs from the business model in that it shares neither its focus on activities nor its central purpose of explaining how value is created. Nonetheless, business model researchers could draw on this literature to identify interesting and important research questions, especially about the origins of business models.

The central concern of research on new organizational forms has been one of understanding why and how new organizational forms come into being. This question has been approached through a wide range of perspectives and different theoretical lenses. In her review work, Romanelli (1991) identified three dominant approaches in the literature: (a) an organizational genetic view that focuses on characteristic features of organizations and sees variation as a random event; (b) an environmental conditioning view that 
emphasizes the role of environment and exogenous forces in determining variation in organizational forms; and (c) a social system view that sees "organizational form variation to be the products of embedded social organizational interactions" (Romanelli, 1991: 81).

Drawing an analogy with the business model literature, this leads us to ask: Why and how do business models come into being? Do they emerge as part of an evolutionary dynamic, or are they purposefully designed by entrepreneurial actors? Which parts of the design process are planned, and which parts are emergent? And what are the implications of these various processes for the resulting business model designs? What is the role of the environment and of social processes in shaping business models? How much variation is there among business models, and what types and extent of variation really matter (e.g., for value creation or for value capture by the focal firm)?

Ecosystems. According to the Encyclopadia Britannica (2010), an ecosystem is "the complex of living organisms, their physical environment, and all their interrelationships in a particular unit of space." From the sciences, the analogy has spread to organization theory. Moore (1996) declared that the term "industry" should be replaced with the term "business ecosystem," which is an economic community supported by a foundation of interacting organizations and individuals. As in natural ecosystems, firms cannot thrive alone; they depend on each other for their effectiveness and survival (Iansiti \& Levien, 2004). In many situations different firms, not necessarily from the same industry, are drawn together in a relationship of complementarity or even dependency. Power and 
Jerjian (2001) propose that the ecosystem metaphor provides an interesting lens through which to approach the idea of value generation through cooperation. In support of this idea, Adner and Kapoor (2010) have found that the success of an innovating firm often depends on the activities performed by third parties in its environment.

The ecosystem concept could be viewed as closely related to the notion of the business model because it recognizes the need to go beyond a focal firm's boundaries and adopt a more systemic perspective that emphasizes interdependencies and complementarities between a firm and third parties in order to properly understand how value is created. Yet, in contrast to a business model, an ecosystem is not anchored on a focal firm; different firms can share the same ecosystem, yet have very different business models. This insight can inspire new research at the intersection of business models and ecosystems. One important question is how firms adapt their business models to an evolving ecosystem. Pierce (2008: 325$)$ found that "the actions of core firms in business ecosystems can have widespread and severe effects on complementors, and monitoring and understanding the actions of these core firms must be of primary importance to managers." How do we know what actions of ecosystem players matter for a focal firm's business model? When would be the right time to adapt one's business model, given the possibility that further change might happen in the ecosystem? How can managers of focal firms achieve maximum fit between their business model and ecosystem, and what exactly defines such fit? 
Activity systems. Research on activity systems has yielded insights on widely diverging phenomena such as the social nature of knowledge production (Engestrom \& Middleton, 1998), taking advantage of technology through new business arrangements (Piccoli \& Ives, 2005), and how to balance cooperation and competition (McLure \& Faraj, 2005). This research forms an important basis from which to describe and analyze business models. The business model conceived as an activity system is a set of interdependent organizational activities centered on a focal firm, including those conducted by the focal firm, its partners, customers, or vendors, etc. (Zott \& Amit, 2010).

Because discrete activities often influence one another, the activity system approach emphasizes interdependencies and the importance of fit (Siggelkow, 2002). Three types of fit have been described (Porter, 1996). The first type of fit is consistency between an activity and the firm's strategy. Consistency ensures that the competitive advantage arising from activities accumulates and does not erode or cancel out. The second type of fit occurs when activities are mutually reinforcing. According to Milgrom and Roberts (1990, 1995), activities are complements when the marginal value of one activity increases as the other activity is increased. Finally, the third type of fit goes beyond activity reinforcement to produce global optimization; it is a system-level type of fit, which optimizes the entire set of activities to eliminate redundancies and minimize waste. Understanding the context of interactions may be crucial in order to understand the sustainability of competitive advantage (Porter \& Siggelkow, 2008). When the competitive landscape changes dramatically, firms face the challenge of reassessing their 
set of activities and deciding which ones to keep performing and which ones to discontinue (Siggelkow \& Levinthal, 2003).

The activity systems literature thus suggests that business model researchers need to develop a more fine-grained understanding of how to design business models that (a) are internally consistent (i.e., where the activities mutually reinforce each other), (b) are as a whole consistent with other elements that characterize a focal firm, such as its strategy or the design of its internal organization (hierarchies, roles, incentives, etc.), and (c) are consistent with the business models of other firms that contribute by performing activities that are part of the focal firm's business model. In other words, we need to understand better how Porter's (1996) typology of fit applies to business models, what fit (or misfit) means, what the performance implications are of various forms of (mis)fit, and what brings about (mis)fit. These questions are not only of an academic nature, but of potentially high interest for practicing managers who need to design, steer, and manage properly functioning and well-performing firms along with their business models, strategies, internal organization, and external collaborations.

Value chain. The value chain includes activities performed during the flow of goods and services from raw materials to consumption (Porter, 1985). It differentiates between primary activities that have a direct impact on value creation (such as inbound logistics, operations, outbound logistics, marketing and sales, service) and secondary activities (e.g., administrative functions, technology, human resource management, procurement) that affect value creation only through their impact on the performance of the primary activities. Value is created by activities that reduce buyer costs or raise buyer 
performance through product differentiation. The value chain thus focuses on value creation at the firm level.

The concept of value chain has been influential by representing and analyzing firm-level value creation. However, its sequential character has been considered increasingly inadequate to the analysis of value creation processes in firms, as the economy saw the birth of new networked organizational forms and the growth of service firms, both of which differ from the traditional manufacturing firms for which the value chain was originally conceived (Stabell \& Fjeldstad, 1998). Concepts such as open innovation (Chesbrough \& Appleyard, 2007), innovation value chain (Hansen \& Birkinshaw, 2007), industry architecture (Jacobides, Knudsen, \& Augier, 2006), and value networks (Allee, 2002; Normann \& Ramirez, 1993) came in response to the limitations embedded in the value chain framework. Much of this emerging body of work, however, has been focusing on the emergence and evolution of structures and dynamics at the network or industry levels (Brusoni, Jacobides, \& Prencipe, 2009).

The notion of the business model, in contrast, represents an extension of the value chain idea that remains centered on a focal firm. The business model concept draws on arguments that are central to the value chain framework, in particular on the ideas that activities and multiple sources of value matter. It also extends those arguments in important ways: (a) by focusing on total value creation (Brandenburger \& Stuart, 1996), (b) by emphasizing value creation and delivery dynamics, and (c) by allowing for a nonlinear sequencing of interdependent activities. 
While the original value chain concept is too limited in scope for the analysis of the value creation processes associated with new business models, further research needs to be carried out on the often complex and intricate mechanisms and dynamics of value creation and capture in a focal firm's boundary-spanning activity system.

\section{Conclusion}

Although the scholarly community is still in the early stages of developing the business model as a new level and unit of analysis for organization and strategy research, our research has anchored the concept theoretically, and it has shown it to be a robust, useful construct for strategic analysis. Increasing consensus on the theoretical foundations, the definitions, and the fundamental properties of business models should lead to the emergence of more broadly accepted concepts and typologies. Empirical research on the measurement of business models and business model innovations, structured to capture all lines of a firm's business that have revenue potential, holds great promise to enhance our understanding of wealth creation. Examining the dynamics of business model evolution (how they emerge and how they are shaped and adapted by entrepreneurial actors over time) — as well as how business models co-evolve with product market strategy and organization design-reflects an important cross-disciplinary research program that will substantially solidify the business model as a pivotal level and unit of analysis in our understanding of value creation and capture. 


\section{References}

Adner, R., \& Kapoor, R. (2010). Value creation in innovation ecosystems: How the structure of technological interdependence affects firm performance in new technology generations. Strategic Management Journal, 31, 306-333.

Allee, V. (2002). The future of knowledge: Increasing prosperity through value networks. Boston: Butterworth-Heinemann.

Amit, R., \& Zott, C. (2001). Value creation in e-business. Strategic Management Journal, $22,493-520$.

Amit, R., \& Zott, C. (2012). Creating value through business model innovation. Sloan Management Review, 53(3), 41-49.

Amit, R., \& Zott, C. (2013). Crafting business architecture: The antecedents of business model design. (Working paper)

Brandenburger, A. M., \& Stuart, H. (1996). Value-based business strategy. Journal of Economy and Management Strategy, 5, 5-25.

Brusoni, S., Jacobides, M. A., \& Prencipe, A. (2009). Strategic dynamics in industry architectures and the challenge of knowledge integration. European Management Review, 6(4), 209-216.

Casadesus-Masanell, R., \& Ricart, J. E. (2010). From strategy to business models and to tactics. Long Range Planning, 43, 195-215.

Chesbrough, H. W., \& Appleyard, M. M. (2007). Open innovation and strategy. California Management Review, 50, 57-76.

Chesbrough, H. W., \& Rosenbloom, R. S. (2002). The role of the business model in capturing value from innovation: Evidence from Xerox Corporation's technology spinoff companies. Industrial and Corporate Change, 11, 533-534.

Daft, R. L., \& Lewin, A. Y. (1993). Where are the theories for the "new" organizational forms? An editorial essay. Organization Science, 4(4), i-vi.

Djelic, M., \& Ainamo, A. (1999). The co-evolution of new organizational forms in the fashion industry: A historical and comparative study of France, Italy, and the United States. Organization Science, 10, 622-637.

Ecosystem. (n.d.). In Encyclopadia britannica online. Retrieved from <http://www.britannica.com/EBchecked/topic/178597/ecosystem>. Accessed: 22 September 2010. 
Engestrom, Y., \& Middleton, D. (1998). Cognition and communication at work. New York: Cambridge University Press.

Hansen, M. T., \& Birkinshaw, J. (2007). The innovation value chain. Harvard Business Review, 85, 121-130.

Iansiti, M., \& Levien, R. (2004). The keystone advantage: What the new dynamics of business ecosystems mean for strategy, innovation, and sustainability. Boston, MA: Harvard Business School Press.

Jacobides, M. G., Knudsen, T., \& Augier, M. (2006). Benefiting from innovation: Value creation, value appropriation and the role of industry architectures. Research Policy, 35, $1200-1221$.

McKendrick, D. G., \& Carroll, G. R. (2001). On the genesis of organizational forms: Evidence from the market for disk arrays. Organization Science, 12, 661-682.

McLure Wasko, M., \& Faraj, S. (2005). Why should I share? Examining social capital and knowledge contribution in electronic networks of practice. MIS Quarterly, 29(1), 3557.

Milgrom, P., \& Roberts, J. (1990). The economics of modern manufacturing technology, strategy, and organization. The American Economic Review, 80(3), 511-528.

Milgrom, P. R., \& Roberts, J. (1995). Complementarities and fit: Strategy, structure, and organizational change in manufacturing. Journal of Accounting and Economics, 19, 179208.

Moore, J. F. (1996). The death of competition: Leadership and strategy in the age of business ecosystems. New York: Harper Business.

Normann, R., \& Ramirez, R. (1993). From value chain to value constellation: Designing interactive strategy. Harvard Business Review, 71(4), 65-77.

Piccoli, G., \& Ives, B. (2005). IT-dependent strategic initiatives and sustained competitive advantage: A review and synthesis of the literature. MIS Quarterly, 29(4), 747-776.

Pierce, L. (2008). Big losses in ecosystems niches: How core firm decisions drive complementary product shakeouts. Strategic Management Journal, 30, 323-347.

Porter, M. E. (1985). Competitive advantage: Creating and sustaining superior performance. New York: Free Press.

Porter, M. E. (1996). What is strategy? Harvard Business Review, 74, 61-78. 
Porter, M., \& Siggelkow, N. (2008). Contextuality within activity systems and sustainability of competitive advantage. Academy of Management Perspectives, 22(2), 34-56.

Power, T., \& Jerjian, G. (2001). Ecosystem: Living the 12 principles of networked business. Harlow: Pearson Education Ltd.

Romanelli, E. (1991). The evolution of new organizational forms. Annual Review of Sociology, 17, 79-103.

Romme, A. G. L. (2003). Making a difference: Organizations as design. Organizational Science, $14,558-573$.

Rousseau, D. (1985). Issues of level in organizational research: Multi-level and crosslevel perspectives. Organizational Behavior, 7, 1-37.

Siggelkow, N. (2002). Evolution toward fit. Administrative Science Quarterly, 47, 125159.

Siggelkow, N., \& Levinthal, D. A. (2003). Temporarily divide to conquer: Centralized, decentralized, and reintegrated organizational approaches to exploration and adaptation. Organization Science, 14(6), 650-669.

Skeuomorph. (n.d.) In Wikipedia. Retrieved from $<$ http://en.wikipedia.org/wiki/Skeuomorph>

Stabell, C. B., \& Fjeldstad, Ø. D. (1998). Configuring value for competitive advantage: On chains, shops, and networks. Strategic Management Journal, 19(5), 413.

Teece, D. J. (2007). Explicating dynamic capabilities: The nature and microfoundations of (sustainable) enterprise performance. Strategic Management Journal, 28, 1319-1350.

Zajac, E. J., Golden, B. R., \& Shortell, S. M. (1991). New organizational forms for enhancing innovation: The case of internal corporate joint ventures. Management Science, $37,170-184$.

Zott, C., \& Amit, R. (2007). Business model design and the performance of entrepreneurial firms. Organization Science, 18, 181-199.

Zott, C., \& Amit, R. (2008). The fit between product market strategy and business model: Implications for firm performance. Strategic Management Journal, 29, 1-26.

Zott, C., \& Amit, R. (2010). Designing your future business model: An activity system perspective. Long Range Planning, 43, 216-226. 
Zott, C., Amit, R., \& Massa, L. (2011). The business model: Recent developments and future research. Journal of Management, 37 (4), 1019-1042. 